\title{
What's new on How Does Law Protect in War? Online
}

\section{Annual update on case studies published from January to December 2017*}

\section{How Does Law Protect in War? Online}

How Does Law Protect in War? Online is a platform adapted from the original reference Casebook published by the ICRC. ${ }^{1}$ It was originally intended to support teaching of international humanitarian law (IHL) in universities in an interactive way, based on contemporary practice. The section on "The Law" features a general outline presenting IHL in fourteen chapters. It contains comprehensive bibliographic resources and links each theme to a range of related case studies and documents. The section on "The Practice" comprises more than 300 case studies and documents regrouped by theme, region or type of document. They allow practice-oriented learning of IHL rules and interactive discussions through a series of questions. The "Pedagogical Resources" section provides useful advice on how to teach IHL, as well as twenty-nine model course outlines and other useful resources. The "A to Z" section presents 422 notions linked to IHL, their legal sources, the case studies where they are addressed, and bibliographic resources for delving further into those notions. A search engine allows users to find rapidly the relevant pedagogical material they need on the platform. 
The annual update on How Does Law Protect in War? Online presents the new case studies and international humanitarian law (IHL) teaching materials published in 2017 on How Does Law Protect in War? Online. ${ }^{2}$

Eighteen new case studies were published in 2017, along with three thematic highlights. Those new teaching materials are presented below. Case studies are prepared by students of the University of Geneva, Faculty of Law, and the Geneva Academy of IHL and Human Rights, under the supervision of Professor Marco Sassòli and Ms Yvette Issar, Research Assistant, both at the University of Geneva. The International Committee of the Red Cross (ICRC), through its Law and Policy Forum, provides technical and promotional support for this content and manages the platform.

\section{Using case studies in IHL teaching}

Teaching IHL with case studies offers many benefits. First and foremost, learning is acquired and integrated into long-term memory more easily when the methods used encourage participants to be actively involved. The fact that a case study is drawn from the realities of armed conflicts holds the students' attention because they can link it to daily life. It also allows them to understand the practical implications of the law. Moreover, discussions in class or group work on case studies develop skills that are in high demand in the labour market and too rarely trained in universities, such as critical thinking, problem-solving, negotiating and accepting diverse opinions. Finally, this method enriches the teacher-student relationship, which additionally stimulates the learning process.

\section{New case studies, January-December 2017}

\section{Africa}

- Central African Republic: Sexual Violence by Peacekeeping Forces discusses the implementation of IHL by multinational forces not directly under the command of the United Nations (UN), the definition of sexual violence according to the UN and according to IHL, and the responsibility to investigate allegations of rape and other forms of sexual violence in armed conflict.

- The case study Libya, NATO Intervention 2011 explores IHL rules governing the conduct of hostilities, as well as repression of possible violations. It also deals with the complex implications of multinational operations for the application and implementation of IHL.

- Libya, Report of the Office of the UN High Commissioner for Human Rights discusses several alleged violations of IHL throughout 2014 and 2015,

1 Marco Sassòli, Antoine Bouvier and Anne Quintin, How Does Law Protect in War?, 3rd ed., ICRC, Geneva, 2011.

2 Available at: casebook.icrc.org. 
including attacks on densely populated residential areas in a number of Libyan cities.

- Mali, Accountability for the Destruction of Cultural Heritage concerns the destruction of mausoleums in Timbuktu in 2012 and the International Criminal Court's first trial on destruction of cultural property.

- In Somalia, Traditional Law and IHL, the question of universality and cultural relativism of IHL is explored, as well as the use of traditional law to disseminate IHL's main protective messages so that they can be known and respected.

\section{Asia and the Pacific}

- Afghanistan: Attack on Kunduz Trauma Center comes back to the question of identification of medical facilities, conditions for their loss of legal protection, IHL rules on precautions before attacks, and requirements for investigations of possible violations.

- Myanmar, Forced Population Movements examines the situation faced by Muslim communities in Myanmar and in neighbouring countries. It analyzes the way in which many reported practices are addressed by different potentially applicable legal frameworks.

\section{Europe and Central Asia}

- The 2016 ICTY judgment Prosecutor v. Radovan Karadzic examines the legality of various shelling and sniping incidents during the siege of the city of Sarajevo, between 1992 and 1995.

- In Sweden/Syria, Can Armed Groups Issue Judgments?, a Swedish District Court discuss whether non-State armed groups have the capacity under IHL to establish courts and impose penal sentences under certain specific circumstances.

- In United Kingdom, G4S Contracts in Israeli-Occupied Territories Face Major Investigation, a security company provided Israel with surveillance equipment at its checkpoints in the occupied territories. This allows for a discussion on the legal basis for IHL to apply to business enterprises and on the actual situations in which it applies.

\section{Middle East}

- Iraq, Forced Displacement and Deliberate Destruction focuses on the legality under IHL of major displacements and actions taken to prevent the return of displaced persons in northern Iraq in 2014 and 2015.

- Israel/Palestine, Operation Protective Edge analyzes the conflict that took place in 2014 in Gaza. It allows many discussions about IHL rules on the conduct of hostilities in one of the most densely populated areas on earth.

- Syria, Destruction of Cultural Heritage shows that heritage sites are sometimes being used for military purposes or have been transformed into battlefields, including the Aleppo Citadel, the Damascus Citadel and the National Museum of Damascus. 
- The case study Syria, Press Conference with French President Francois Hollande and Russian President Vladimir Putin focuses on the Syrian conflict and deals with complex classification issues, the territorial scope of application of IHL, the definition of military objectives and the protection of humanitarian assistance under IHL.

- Yemen, Naval Blockade highlights some of the (in)direct effects of conflicts. Disruptions of the food, water and medical supply chains have an impact on the civilian population and on hospitals, which are often located in cities, as is the case in Yemen.

\section{Others}

- The ICRC 2015 Report on International Humanitarian Law and the Challenges of Contemporary Armed Conflicts summarizes various challenges faced by IHL, including but not limited to multinational forces, detention, new technologies and terrorism. It also communicates the ICRC's position on many of those issues. The Index $(\mathrm{A}-\mathrm{Z})$ allows readers to find the exact paragraph in this long report dealing with a certain issue (e.g., internationalized internal armed conflict, military necessity, equality of belligerents, private military and security companies, humanitarian assistance, proportionality).

- The case study UN, Report of the Secretary-General for the World Humanitarian Summit addresses the crucial question of implementation of IHL in the beginning of the twenty-first century, as well as the related responsibility of States, and the roles of the International Red Cross and Red Crescent Conference, the ICRC and Switzerland.

- UN, Security Council Resolution 2286 on Attacks on Hospitals discusses the purpose and effects of that Resolution and compares its prescriptions with IHL requirements, in particular with regard to the protection of medical personnel, medical objects and the emblem.

\section{New thematic highlights, January-December 2017}

IHL, Protecting Human Life and Dignity in XXI Century Wars highlights six new case studies, allowing teachers, students and professionals to explore some of the most salient aspects of IHL in today's armed conflicts through interactive discussions. The twenty-first-century challenges presented here include multinational operations, legal protection of hospitals and sexual violence in armed conflict.

War in Cities presents eight new case studies that illustrate the ways in which wars are fought in cities and the challenges such trends raise in recent and contemporary contexts. These cases allow teachers, students and professionals to dig into three challenges related to urban warfare, namely the conduct of hostilities, the reverberating effects of violence on vital services and the threat to cultural heritage. 
The "A to Z" section may now be used as a kind of online IHL "dictionary": this highlight presents a major enhancement to the "A to Z" section of How Does Law Protect in War? Online. Ninety-seven new definitions have been added, and several hundred changes have been made to improve its content. The "A to Z" section now contains references for 422 key IHL terms. This work has been conducted in partnership with the University of Geneva, Faculty of Law, and the Geneva Academy of IHL and Human Rights. 